\title{
The image of violence and the violence of the image
}

War and ritual in Assyria (Ninth - seventh centuries BCE)

\section{Imagem da violência e violência da imagem \\ Guerra e ritual na Assíria (séculos IX-VII a.C.)}

Marcelo REDE

Departamento de História

Universidade de São Paulo

Avenida Professor Lineu Prestes, 338, SP, São Paulo, 05.508-000, Brasil

mrede@usp.br

Abstract The idea of a predominantly bellicose and cruel Assyrian Empire (Ninth - Seventh centuries BCE) was based on certain visions inherited from the past (ranging from classical authors to the Hebrew Bible). From the nineteenth century onwards it developed following archaeological discoveries and the deciphering of cuneiform texts. Alongside official documents (inscriptions, annals, etc.), the images of the reliefs of Assyrian palaces played a central role in this construction. Considering this vision as the result of ideological and propagandistic manipulation of royal discourse and identifying an acritical approach of modern historiography is necessary, but not sufficient. This article seeks to offer an alternative appreciation. It proposes that it is necessary to conceive images of violence as active agents of the social phenomenon of sacred war, in a context of a process of expansion. The responses point in a dual direction: first to the relationship between visual violence and the specific type of Assyrian expansionism; in second place, to the ritual nature of visual artefacts.

KEYWORDS image, violence, imperialism

Received: 9 Aug. 2017 | Reviewed by the author: 25 Sept. 2017 | Accepted: 29 Sept. 2017 http://dx.doi.org/10.1590/0104-87752018000100004

Varia Historia, Belo Horizonte, vol. 34, n. 64, p. 81-121, jan/abr 2018 
Resumo A ideia de um Império Assírio (séculos IX-VII a.C.) predominantemente belicoso e cruel fundou-se em algumas visões herdadas do passado (dos autores clássicos à Bíblia hebraica) e desenvolveu-se com as descobertas arqueológicas e o deciframento dos textos em cuneiforme, a partir do século XIX. Ao lado dos documentos oficiais (inscrições, anais etc.), as imagens dos relevos dos palácios assírios tiveram um papel central nessa construção. Considerar essa visão como resultado de uma manipulação ideológica e propagandística do discurso régio e identificar uma abordagem acrítica da historiografia moderna é necessário, mas não suficiente. Este artigo busca oferecer uma apreciação alternativa. Propõe-se que é preciso conceber as imagens da violência como agentes ativos do fenômeno social da guerra sagrada, no quadro de um processo de expansão. As respostas apontam em uma dupla direção: primeiramente, para a relação entre a violência visual e o tipo específico de expansionismo assírio; em segundo lugar, para a natureza ritual dos artefatos visuais.

Palavras chave imagem, violência, imperialismo

The scene is well known: ${ }^{1}$ King Ashurbanipal (668-627 BCE) reclining on a finely decorated sofa; supported by his left elbow, holding in one of his hands a lotus flower; in the other, a cup. In front of him is his queen, sitting on an elevated chair, with her feet supported. She is holding a bouquet of flowers and raising a goblet to her lips. Everything is taking place in an ornate garden of palm trees and spruce; a vine, regurgitating clusters of grapes, frames the couple. Small birds land on the trees. The

1 The panel known as the 'Banquet Scene' is part of the set of alabaster reliefs found in room S (certainly coming from the upper floor which had collapsed, $S^{1}$ ) of the north palace (bit riduti = "palace of the prince"), in Nineveh. Currently it is part of the British Museum collection (WA 124920); Cf. BARNETT, 1976, p.57 and p. LXIII-LXV and READE, 1998, fig. 106 and 107. For the probable position of the panel in the set and in the architecture of the enclosure, see KERTAI, 2015, p.179-181. 
sovereigns are being fanned and served with snacks on trays. Music fills the atmosphere. ${ }^{2}$

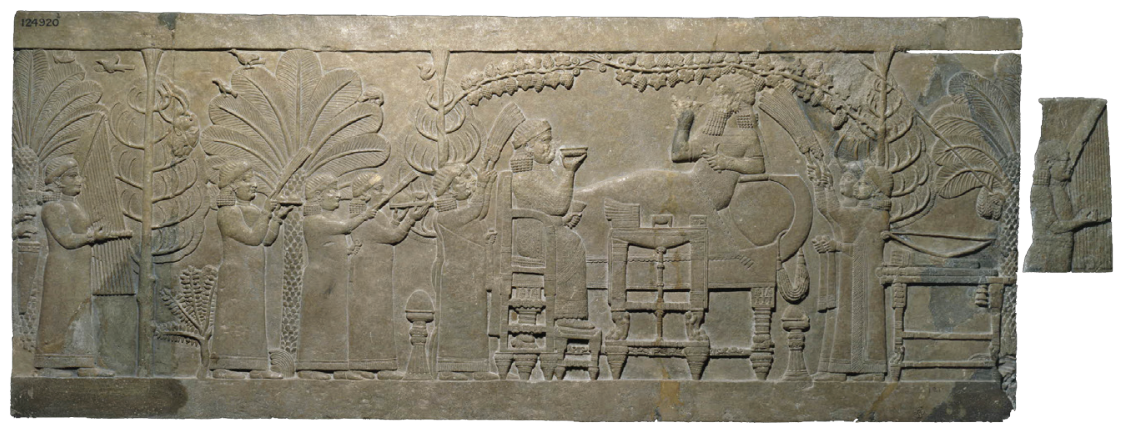

Figure 1: Banquet Scene $\odot$ Trustees of the British Museum.

The landscape is bucolic and many of its elements contribute to reinforce the mood of enjoyment and splendor proper to the life of royalty. On the extremities of the scene, two elements remind us that every delight has its conditions. Behind the king, on a side table, rest his sword, bow, and quiver with arrows. It cannot be excluded that the purpose of this is to situate the banquet scene in the sequence of a hunt (this is what is suggested by Benoit, 2003, p.403), inserting it in a narrative cycle that was frequent in Assyrian palace reliefs (Lion; Michel, 2006, p.225 and ss). However,

2 The queen is probably the principal wife of Ashurbanipal, Libbali-sharrat. The identification of secondary characters is controversial. 'The Banquet Scene' is just one of the panels (C) which compose a greater set. On the left (panel B; of which we can see the right extremity in Fig. 1), the line of people continues, they look similar to those serving the royal couple, but they carry musical instruments. Even further to the left, in the upper part of another panel (A), there is a sequence of people, varied in clothes and postures; three are on the ground, bowing; this panel contains an epigraph of three lines in cuneiform. To the right of the banquet, the panel (D) is badly preserved, but parts of the servants can be identified, followed by more servants and musicians (panel E). In the composition, Barnett saw a female orchestra, servants, and on the left "prisoners of royal and princely rank," prostrated on the ground, asking for clemency or carrying food. Also, according to Barnett, the epigraph inscribed in panel (A) helps in the identification of the Elamite and southern Babylonian princes serving the king. BARNETT, 1976, p.56. The identification of the former servants and musicians as female seems plausible: MACGREGOR, 2003, p.55 and ss and MELVILLE, 2004, p.42. The epigraph of panel (A) should thus only refer to its own characters; cf. GERARDI, 1988, p.25, whose translation confirms the mention of only the Elamites. 
the hunt, particularly of the lion, a royal apotheosis, semantically approximates war: both compose the theme of the heroic act carried out by the king against adversaries, whether wild beasts or mundane enemies (Albenda, 1974), ${ }^{3}$ reaching cosmic dimensions in the struggle of order against chaos (Cassin, 1987, p.196 and ss, p.201 and ss). ${ }^{4}$ Furthermore, in Assyrian iconography, many elements suggest the hunt as a ritualized performance of the king in association with the triumphal procession after victory in combat (Weissert, 1997, p.348 and ss). ${ }^{5}$ Hunting and war were complementary, they were equivalent, one meant the other.

On the other hand, directly in Ashurbanipal's field of vision, the warlike evocation does not leave any room for doubt: the severed head of Teumman, the Elamite, hangs from a ring on a branch of a tree. It is only a stage, the final one, of the misfortunes of the defeated monarch. The violent moments before his downfall are detailed in the reliefs in Room I of the north palace and also the other palace in Nineveh. ${ }^{6}$ The information contained in these images (some containing epigraphs or labels),

3 The choice of the lion as the prestigious victim did not prevent the assimilation of the king and the beast, whose position in the animal world is considered dignified enough to be incorporated by the sovereign, cf. WATANABE, 2000, p.407. Variants of the expression 'infuriate/bristle like a lion' (labbiš nadârum) are abundant in Assyrian inscriptions, particularly in contexts in which the sovereign reacts to treason or rebellion. ABUSCH, 2008, suggests that the famous narrative of Gilgamesh and Enkidu confrontation with Humbaba in the Epic of Gilgamesh, was constructed based on the initiation texts of the young prince through hunting.

4 On p.212, she concluded: "Establishing an equivalence between the kings, the object of his wars, and the lions, the target of his hunts, Ashurbanipal relates two different and to some extent opposite worlds, the civilized world in which the king dominates, and the wild world, where the lion is king" (CASSIN, 1987, p.212). Watanabe, in turn, suggests that the Assyrian king's lion hunt replicates at the discursive and iconographic level, the mythological combat of the God Ninurta against the monsters (particularly Anzu); cf. WATANABE, 1998, p.445. In relation to Ninurta's role in royal ideology, cf. ANNUS, 2002, above all p.102 and ss for the royal hunt.

5 The fact that Ashurbanipal did not participate directly in the campaign against Elam does not diminish at all the symbolic potential of the triumphal procession perpetrated in his honor.

6 Above all the reliefs in room XXXIII of the Southwestern palace of Tell Kuyunjik, constructed by Sennacherib, rebuilt by his grandson Ashurbanipal, around 650 BCE, Cf. BARNETT; BLEIBTREU; TURNER, 1998. Also: COLLINS, 2008, p.97 and ss. And RUSSELL, 1991, p.63, p.124, fig. 65. For a description of the representations of the Elamite campaign, cf. ALBENDA, $1976 ; 1977$ (she calls the construction the 'northwest palace,' taking as a reference the old city) and, more recently, the detailed reconstitution of NADALI, 2007. 
royal inscriptions from a dozen tablets, and a prism allow the episodes which constitute the memory of the 653 BCE Assyrian campaign against the Elamites to be recomposed: ${ }^{7}$ in the middle of his soldiers massacred during the Battle of Til Tuba, on the banks of the River Ulai, Teumman fell from his chariot hit by the Assyrians; he tried to flee with the help of his son, Tammaritu, but he received an arrow in the back; falling to the ground he was decapitated by an anonymous soldier; his head was transported off the battlefield in a chariot; brought to Arbela, it was a presented to Ashurbanipal hanging from the neck of a king allied to Teumman, Dunanu; the latter was also tortured and executed shortly afterwards; finally, the head of the Elamite leader was sent on to Nineveh.

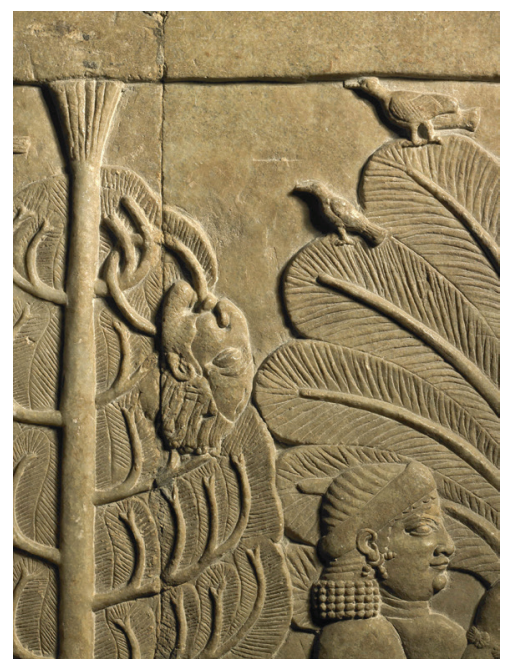

Figure 2: Detail of the severed head of the Elamite king. Banquet Scene. (C) Trustees of the British Museum.

7 Cf. LUCKENBILL, 1989, n. 855 and ss. For the so-called Prism B, cf. BORGER, 1996, p.106 and ss. For the labels and epigraphs of the reliefs, see GERARDI, 1988. The most complete study of the set of texts, architecture, and images is RUSSELL, 1999, p.154 and ss. Elamite inscriptions (supposing the possible identification between the king called Teumman in Akkadian and the Elamite Tepit-Huban-Inshushinak) does not add much information to the scenario; cf. WATERS, 1997, p.78 and ss. The Assyrian correspondence clearly shows that before becoming king in 664 BCE., Teumman already nurtured great animosity towards Assyria. WATERS, 1999, p.473-477. 
The juxtaposition of the banquet and the beheading in a single scene can appear disconcerting. However, should we see it as contradictory? The composition of the Banquet Scene can suggest, to the contrary, complete continuity of meaning between the enjoyment of the moment of peace resulting from victory, with the pleasurable consumption of food and drink to the sound of music, and the horrors of battle. Was the exhibition of the head of the enemy king not simply introducing war and sacrifice at the dining table? Stephanie Reed notes the tension of this visual arrangement "where life and death are juxtaposed, creating a pervasive anxiety" (Reed, 2007, p.112). The apparent ambiguity of the scene allows questions to be asked about the role of the iconography of violence: is it only a discursive artifice of the propaganda of warlike ideology, as defended by an opinion which is still very current, or would the consideration of an agency of image in interaction with social actors allow another response?

\section{IMAGES OF BELLICOSE ASSYRIA: BETWEEN ANCIENT AND MODERN}

The association between the Neo-Assyrian empire (ninth to seventh centuries) and violent and continual warfare is one of the most solid of Mesopotamian historiography, as well as being part of a diffuse imagination. From military action to cultural warmongering, the warrior phenomenon appears to define the Assyrian social group, the key to understanding politics, the economy, arts, literature, religion, and the god Assur. War and its connected aspects - in particular, unlimited cruelty - are presented as a strong ethnic and 'national' component, inherent to a martial Assyria. Conquest without frontiers, severe rule over neighboring regions, and bloody repression of all resistance or rebellion form the context which give meaning to this characterization. At the end of the nineteenth century, in one of the first syntheses of the Assyrians, Archibald Sayce emphasized the distance which separated them from their Babylonian rivals: "The Babylonians were agriculturists, fond of literature and peaceful pursuits. The Assyrians, on the contrary, have 
been appropriately termed the Romans of the East: they were a military people, caring for little else save war and trade. Their literature, like their culture and art, was borrowed from Babylonia, and they never took kindly to it" (Sayce, 1895, p.25; original from 1885). A century later, A. Kirk Grayson, one of the most respected specialists from the period, makes a very similar judgment: "Militarism was at the heart of Assyria's rule over conquered territory because Assyria was a nation of warriors" (Grayson, 1995, p.959).

Two pillars of the occidental tradition strongly nourished this image: Biblical texts and some classical authors. Until the nineteenth century, the moment of the rediscovery of Assyria by archeology and the deciphering of cuneiform texts, these were the principal sources of the Western imagination of the Assyrians.

Mentions of Assyria by classical authors are sparse, even among the Greeks, and at times unspecific, referring to a vaguely Asiatic territory. To a certain extent, Assyrian bellicosity prefigured the specter of an aggressive and invading Persia which, in the fifth century BCE, haunted the Greek poleis. ${ }^{8}$ The Hellenic memory of Assyria was dissipated in a more present and pressing vision of the 'Asiatic,' the 'oriental,' which continued to be, for the Greeks, a threat and source of terror.

In the Hebrew Bible, the image of Assyria is not univocal and serves, above all, the purposes of the metaphoric narrative and the political projects which sought - especially through the voice of prophets - to strengthen positions or survive external threats (Weinfeld, 1986). The greater part of the events thus evoked are related to Assyrian dominion in the Syrian-Palestinian region during the eighth century, between the reigns of Tiglat-Pileser III and Sargon II. These are the most dramatic years which led in $721 \mathrm{BCE}$ to the annihilation of Northern Kingdom,

8 The almost non-existence of a Persian - textual or imagetic - narrative tradition about the conquests and deeds of their sovereigns could have contributed to the Greeks mobilizing confused Assyrian and Babylonian images in the perception of the 'oriental' threat. It is worth noting that the inscription and the images of the Behishtum rocks are, despite their fame, an exception, explicable by the need to justify the ascension of Darius to the throne. BARJAMOVIC, 2012, p.46, no. 9. 
Israel, and the destruction of its capital Samaria and the deportation of a substantial part of its population.

In the nineteenth century, the first reinforcement of the vision of this Assyrian came from images. The Assyrian reliefs and monument had a great impact on the reconstruction of a history that had been buried until then. ${ }^{9}$ A varied repertoire of iconographic motives directly associated with war was exhibited in palace decoration: preparations and encampments; walls under siege, with the use of ladders, battering rams, and supply carts; attacks by infantry and cavalry, archers and lancers; the burning of cities, the plundering of fields, knocking down of trees; plunder, processions of prisoners; the torture, impalement, and dismemberment, and flaying of enemies; piles of severed heads, bodies laid out along roads and battlefields, floating in rivers, and falling from walls; in short, an inventory of horror and carnage. The reception of this material by modern European states in imperialist competition stimulated the warrior imaginary which surrounded the ancient Assyrians (Bohrer, 1998; Holloway, 2002, p.9 and ss; Frahm, 2007).

With the deciphering of cuneiform and Assyrian Akkadian, it was found that the texts essentially pointed in the same direction as the visual sources. ${ }^{10}$ With a palace origin and part of the ideological royal discourse, images and texts crystalized warlike action as the greatest attribute of Assyrian monarch in his 'palace without a rival' (ekal šanina la išû), leading his dominion to the 'four corners of the earth' (šar kibrat erbetti), under the aegis of the 'weapons of Assur' (kakki ša $\left.{ }^{\mathrm{d}} A \mathrm{~s}^{\mathrm{s}} \mathrm{u} u r\right)$, according to the expressions of the time. A reincarnation of the old Sargon of Akkad in his role as the 'king of combat' (šar tamhari). Thus, the appropriations of ancient discourse and the collection of new archeological and epigraphic data consolidated in the nineteenth century, the vision of Assyrian warmongering, prolonged to a great extent in

9 The initial concentration of excavations on the palaces in Northern Mesopotamia - Kalhu, Dur Sharrukin, Nineveh - contributed decisively to equate, and even confuse, the first modern perspectives of Mesopotamia with Assyria. LARSEN, 2001.

10 For an overview of the documentary corpus, cf. FALES, 2006. 
the most recent historiography. ${ }^{11}$ If an alternative tendency comes to light, it is an attempt to nuance the exaggerations of martial grandiloquence of inscriptions and the official annals based on the analysis of the most daily aspects of the warrior life, present in the vast palace correspondence (Malbran-Labat, 1984). Others highlight the administrative mechanisms, some innovative, which marked the organization of imperial territory (Pecirková, 1977; 1997; Villard, 2008). However, the Assyria of historians never removed its warrior clothing.

\section{REALITIES OF WARFARE:}

\section{A FLACID EMPIRE AND ELOQUENT IMAGES}

The question that arises is if it is possible or necessary to abandon this warmongering vision, relegating it to the category of ideological masks or historiographic drifts. There is no doubt that the Assyrians used the discourse and image of war as a mechanism for the valorization of their expansionist action. A critique of the ideological bias of the sources is legitimate and indispensable. However, it is an error to bet on a radical deconstruction, so much to the taste to a certain current form of historiography. Bellicose Assyria is a dual fiction, ancient and modern, but it does not stop being an aspect inherent to the historical realities of the past.

Restated in these terms, the problem of Assyrian warmongering requires a contextualized explanation, which links it with the situation of disputes for power in the Mesopotamian scenario and with the external expansion movement. The emphasis on war was, to various degrees, a constant in Mesopotamian history, but it assumes a greater emphasis in the Neo-Assyrian empire. Without being able to exhaust the problem, it is possible to list some factors which helped to understand the reason for this dimension, to a large extent new.

The first factor is related to the situation of heightened competition in Mesopotamia. The constant tension and the episodes of open conflict between Assyria and Babylonia were the rule for the first half of the first

11 For a critical overview, FALES, 2010, p.52 and ss. 
millennium. ${ }^{12}$ Assyria obtained an initial advantage. Since the beginning of the ninth century, and for more than a century and a half, the existence of Babylonia oscillated in function of an Assyrian predominance which sometimes gave it as greater autonomy, sometimes the condition of vassal. The city-kingdom of Marduk received a succession of kings from various origins - Chaldeans, Assyrians, Babylonians, - in general with a weak pulse and short life. The effective incorporation of Babylonian into the Assyrian empire by Tiglat-Pileser III, in 728 BCE, consolidated the intention to form an internal territorial block, at the same time that it opened the way to incursions into surrounding areas. While, under the reign of Merodach-Baladan II (721-710), Babylonia demanded independence and imposed severe reverses on the Assyrians Sargon II and Sennacherib, the following period stabilized the dominion of Assyria. A tenuous stability, it is true, since local revolts never ceased. In one of them, the viceroy of Babylonia, Ashur-nadin-shumi, son of Sennacherib, was deposed and handed over to the Elamites by rebellious Babylonians. His execution led to the paternal angry revenge by the Assyrian king and the great devastation of the capital of Babylonia in 689 BCE. Sennacherib's successor, Esarhaddon, perceived, however, that Babylonia, too powerful and too prestigious, could not be simply annihilated. During his reign, between 690 and 669, he adopted a policy of appeasement and foresaw a succession based on the solution of two kingdoms, whose thrones were destined, from 668 onwards, to two of his children, Ashurbanipal in Assyria, and Shamash-shumuukin in Babylonia. The kinship which united the brothers did nothing to dissipate the tensions: at the beginning, the grandmother of both - Sennacherib's influential queen, Zakutu - put together a treaty of loyalty (adê) to Ashurbanipal, sworn by his brothers; from the beginning, it was clear that the autonomy of Babylonia was more apparent that effective and met its limits in the designs of Assyria; seventeen years later, Shamash-shumu-ukin led the Babylonians to a great rebellion,

12 See, in general: BRINKMAN, 1979; GALTER, 2009. 
harshly put down. ${ }^{13}$ The conflict with Babylonia, however, exposed Assyrian weaknesses. The balance changed definitely a few years later, with the emergence of a new dynasty in Babylonia under Nabopolassar (625-605). It seems quite evident that, during the entire period of submission, Babylonia aimed at the destruction of the Assyrian enemy and did everything to assume its place. No alternative which implied a real accommodation was seriously considered and each Babylonian movement constituted - to return to the useful expression of J. A. Brinkman (1984) about the period - a prelude to empire.

Weakened and impotent, Assyria saw the ascension of a new mistress of Mesopotamia. In alliance with the Medes, Babylonia successively destroyed the principal Assyrian centers: Assur, in 614; Nineveh, annihilated in 612; Harran, where the Assyrians entrenched themselves in search of political survival, conquered in 610. At the end of this conflict, Assyria disappeared from the political map of the Near East.

Therefore, it is foolish to say that the militarization of Babylonia was less emphatic that that of Assyria, even if the royal Babylonian discourse had been stripped almost completely of its warmongering references (Jursa, 2014, p.122). The competitive process in the valleys between the Euphrates and the Tigris reached a level which would only admit exclusive dominion and propelled an unprecedented military investment, by both parties. The result of the process, Babylonian victory, showed that Assyria was not the only 'warrior nation' at that time. The bipolarity hid an irremediable tendency towards unitary power, stimulating, on both sides, destructive potential based on the logic of war.

Inter-regional geo-politics was equally affected. This is my second point. In the first millennium, the limits of Assyrian action were successively widened, spilling over the traditional frontiers which limited sovereigns in the Middle-Assyrian period, at the end of the second millennium (Tenu, 2009; Caramelo, 2011 for Middle-Assyrian expansion). In an initial phase, from the ninth century BCE, confrontations occurred

13 These dramatic events resulted in frenetic divinatory consultations, studied by CARAMELO, 2010. 
in the northeast, against the Urartu, on the edge of the Caspian Sea, and against the Mannaens - in other words, fighting porous and dispersed political units, characterized by the tribal groups of the mountain people in the Zagros region -, and in the northwest, in the Trans-Euphrate, against the kingdoms which were established in the old zone of Hittite domination, from an Aramaic strata, such as those (inadequately) called neo-Hittites, extending from the upper course of the Euphrates to the Taurus Mountains, passing through Syria. Dominion in this region prepared the path to advance beyond the Taurus and to Cilicia. From early on, however, and above all from the middle of the eighth century BCE, the expansion movement pointed clearly towards the Syro-Palestinian corridor, the Levantine coast, opening a never completely explored gate to the Mediterranean (which would be limited to the imposing of tribute and the vassalage of some Cypriot kings), and, more ambitiously even to Egypt, in which Assyrian dominion was ephemeral and superficial, although the incursions of Esarhaddon and Ashurbanipal had contributed to put an end of the 'foreign' Kushite dynasty and, in alliance with potentates from the Delta, had stimulated the foundation of the new Saite dynasty, with Necho and Psammetichus.

Geographical amplitude should not, however, induce a mistaken vision of Assyrian expansion. It was not a spatially continuous empire, formed by a successive annexation of territories which would come, however, to be governed as part of a more or less homogenous whole, in which the basic hierarchy is represented by the opposition between a center and the provinces. If this had been the case, the war apparatus would essentially be an instrument of conquest. From the annexation onwards, the periphery would have gradually been controlled by more administrative mechanisms. Military force would always be present, but transformed into a guarantee of the maintenance of local order and submission to the Assyrian king. Evidently, all of this also occurred in the Assyrian case, to a limited degree. Some historians believe that the situation was only initial, and was altered in a consistent manner by the administrative integration of the empire by Tiglat-Pileser, from 745 BCE. However, this seems to me to be an exaggeration. In fact, various 
reforms aimed at reducing the autonomy of the periphery, transforming old allies and vassals into Assyrian provinces, commanded by governors designated by the king; tax collection, the conscription of troops, and the system of weights and measures were normalized for greater effectiveness; the deportations of populations intensified. All these factors, and others noted by Simo Parpola (2003), do not appear to have guaranteed, however, a decisive alteration of the imperial militarist structure.

In addition to heterogeneity, weakness was constant. ${ }^{14}$ Even the center did not form a compact and totally controlled zone. The plain of steppes marked by hills with a low altitude, the Djezirah, had a very dispersed human occupation and the possible unity was maintained by force, by the presence of military garrisons, and the use of a network of roads controlled directly by the palace, complemented by river navigation. At the time of the imperial apogee and in the central regions, such as Assur and Kalhu, the strong presence of deported Aramaic populations and the incursions of Arab tribes represented obstacles to Assyrian dominion. As was to be expected in more peripheral regions, control was more tepid and unstable. In Syria and the Levant, ${ }^{15}$ Assyrian authority depended enormously on alliances with local kingdoms which, although vassals, always had great autonomy and at time, particularly incited by Egypt, shook things up. Or at least tried, before ending tragically, as in the case of Israel. The scheme functioned in a more or less adequate manner with the Phoenician cities on the coast and with some kingdoms in the interior, such as Edom. Furthermore, military garrisons and some administrative installations sought to guarantee the essential, in other words, the continuity of the flow of taxation. The main routes had a fundamental role, but the preference of the Assyrians for more secure routes which ran from the Euphrates and descended the Orontes, passing Aleppo, Damascus, and the Beqa'a Valley, to reach Galilee, shows that they did not feel at ease to follow the traditional northern

14 For a summary of the geographic horizons by which the Assyrian dominion extended, cf. FALES, 2010, p.162 and ss. The report below is based on Fales' typology.

15 The most detailed recent study for the region is: BAGG, 2011. 
route in the desert, between Habur and Syria, passing by Tadmor (later Palmira), except when armies were moving in campaign. In addition, here the Arab tribes did not give any peace to the Assyrians. Finally, the rocky arc formed by the Tauros and the Zagros delimited a difficult zone, whether populated by mountainous nomads or more complex organizations (although, in general, the Assyrians homogenously represented them as 'kingdoms', according to their own references), and which had in common the complete aversion to Assyrian attempts at control. In general, these were fruitless and, with the exception of seasonal incursions in the higher zones, ended up demonstrating that the piedmont and the valleys between the mountains full of paths were a limit imposed on Assyrian pretentions to sovereignty; ${ }^{16}$ similarly, Assyrian domination of the transhumance of shepherds, not always amicably, depended almost totally on the occupation of towns and villages, as well as protecting the usual routes, in other words rarefied fixed points in a vast virtually uncontrollable space. ${ }^{17}$

Regional and inter-regional connections need to be analyzed in light of the internal political situation in Assyria, where monarchical power faced serious resistance from part of the elite, whether nobles from successive capitals and the principal cities or local governors. The conflictual relationship between the forces of monarchical centralization and centrifugal tendencies was one of the decisive factors for the reproduction of a very unstable endogenous equilibrium even in moments of foreign advances. Although the opposition between the king and the high ranking dignitaries is the object of debate, it seems certain that the administrative reform of Tiglat-Pileser constituted, at least in part, an attempt at the "domestication of the aristocracy" (Demare-Lafont, 1998, p.611 and ss.).

16 Mountains played an essential role in the Assyrian imagination and in the construction of the heroic role of the king: the royal inscriptions offered the ideological translation of the mythological conception of the mountain as a limit between the cosmos and chaos, cradle of all sorts of threats and dangers; see Simonetta Ponchia's excellent study, cf. PONCHIA, 2004; 2006, p.257 and ss for Ashurbanipal.

17 GRECO, 2003, who pointed to, however, a certain economic development resulting from the expansion, benefiting both the Assyrians and some mountainous regions. 
It cannot be said that the expansion project did not enlist the effort, at times enthusiastic, of the Assyrian elite. To the contrary, an essential part of it were offshoots from the palace and the privileged beneficiaries of the fruits of empire: the circle of high ranking officials and members of the court - called rabânu / rabûte, the 'great ones' - acted decisively in the administration of lands exploited by royal concession, in some cases with exemptions from taxation, tax collection, and in the advantages resulting from the division of plunder and of the labor of deportees, not to mention possible gifts from sovereigns (Matilla, 2000, p.137 and ss; Radner, 2011, p.359 and ss). ${ }^{18}$ Adhesion, however, was neither immediate nor automatic, as shown by royal efforts to propagate the imperial ideology among palace officials. In terms of communicative potential and the effectiveness of the message, visual compositions within palaces appear to correspond less to generalized propaganda aimed at terrorizing and dissuading foreign enemies (or coerced allies) or guaranteeing the submission of conquered populations than persuasion aimed at members of the Assyrian palace elite (Liverani, 2017, p.87 and ss). Persuasion which was translated by a real erotic seduction, inciting engagement in war conquest efforts through a 'pornography of violence,' as it was labelled by Seth Richardson (2007, p.198). ${ }^{19}$

18 Two recent volumes specified the links of power and the benefits resulting from the inclusion in the palace structure by part of the women from the Assyrian elite: MACGREGOR, 2012 and SVÄRD, 2015.

19 This internal and centripetal orientation of the 'propaganda' was, however, neglected by most approaches of the first approaches to the theme; see, for example, READE, 1979. More recently, see the interesting analysis by BAHRANI, 2008, p.219 and ss. A pedagogical intention, which produced an elite ethos, it is not necessarily contrary to the suggestion of Mehmet-Ali Ataç that images destined to be visualized almost exclusively by the sovereign, such as the Banquet Scene, were a source of reflection about royalty, about their excessive potential and also their fragilities in the context of an empire which already showed signs of the limits of its expansion, cf. ATAÇ, 2012. The situation is, nevertheless, very complex and varied according to the types of supports and the contexts of their circulation. Barbara N. Porter defends, for example, that a considerable part of the annals and the bas-relief had as a priority audience a restricted temple and palace elite, while other manifestations - from monoliths constructed in recently conquered regions to panels in rooms in the palace with a greater flow, such as Ashurnasirpal's throne room - were detained to have a broader propagandistic impact; the functioning mechanism was, however, not always based on the conspicuous exhibition of 
Also in the ideological domain, it is possible to find signals of inconsistency, and a fundamental problem here is the level of sharing of the culture of imperial dominion by metropolitan and provincial elites. As Michael Mann states, alongside clientelist mechanisms, direct armed control, and compulsory material cooperation, belief in a common set of ideas of governance is an essential ingredient of imperial policy. Dealing with the Neo-Assyrian case, Mann suggests that, unlike the tonic of preceding empires, there appeared in Assyria in the first millennium, in a very innovative manner, a type of 'nationalism,' which was not, however, characterized by a transversal ideology, supported by an entire 'nation' (the very concept would be anachronistic), but by penetrating and connecting the political elite. In this sense, Assyrian religion - and he notes that what is in question here is above all a state dimension of religion had an important role. This 'moral of the upper-class' is however limited to the imperial core, contributing to define an exclusionary opposition in relation to the dominant groups in the periphery (Mann, 1986, p.231 and ss). Following the same line of reasoning, Peter R. Bedford believes, however, that the scope of imperial ideology was broader and that the coopting of local elites through clientelism or imposition ended up including them in an imperial culture of government. For Bedford, it is necessary to make a distinction: it is possible that the peripheral elites were kept marginalized in terms of Assyrian ethnicity or national identity, but this did not prevent their integration in an imperial identity. This was probably the most Assyrian manner of including foreign elites in their symbolic universe, in their vision of the world (Bedford, 2009, p.59 and ss). Very possibly, the explanation for this ambiguity resides in the fact that Assyria experimented in its contacts with the other populations in the empire, a process of cultural cosmopolitism between elites that was only partial and unfinished: according to Seth Richardson, in the absence of a well-established mental ethnographic map, the expansionist project was not based on a systematic effort at acculturation, and nor

violence, but on an alternation between intimidation and amical persuasion regulated in function of the situation; cf. PORTER, 2000; 2003. 
was the question of identity differences clearly placed; in this context of flexibility of ethnic markers, linguistics, style, modes of dressing, and religious practices, the defining element of the status of the elite, whether central or peripheral, was loyalty to the sovereign, manifest in various forms of 'confidence' (documented in the nominal variants of the verb rahâșum); the same connection, established on a case by case basis between the king and the multiplicity of elites, constituted the engine of competition, emulations, and rivalries between the upper layers of society; finally, it is clear that it was also the situation of being trusted by the monarch which positioned elites in relation to subordinate groups, thus loyalty was conspicuously exhibited or demonstrated with ostentation (Richardson, 2016). Here the terms are sensitively different from those which have guided the debate about the 'Assyrianization' of peripheral zones. In general, 'Assyrianization' supposed a much more widespread process, including legal and fiscal standardizations, as well as of the system of weights and measures and the calendar, the use of Aramaic as a lingua franca (which suggests a very pragmatic concession by the Assyrians, avoiding the complication of the forced imposition of the Assyrian language and the Cuneiform script), the sharing of religious and ideological elements, etc. This is said to be the result of a systematic desire for coopting and the imposition on the part of the Assyrians, although it was frequently suggested by diverse authors, does not seem to be based on reality. ${ }^{20}$ The alignment of local elites with new conditions imposed by the Assyrian advance was, above all, a reaction of political convenience and the search for survival as a privileged stratum.

One of the possible results of this particular mode of operating submission mechanisms has perhaps been the lack of importance of the distinction between an internal territory and an external one: ties of dependence were gestated and reproduced above all through individualized relations between all the members of the empire and the king, expressed in oaths of loyalty which did not make a substantial difference between governors, priests, or Assyrian warriors, on the one hand, and

20 In relation to this theme, I support in general terms the opinion of BAGG, 2013. 
foreign rulers or tribal leaders on the other (Barjamovic, 2012, p.53). Bradley Parker (2002, p.375) is correct when he states that in this scenario, "the frontier is transformed from a static line of exclusion to a dynamic zone of interaction". Moreover, the configurations were very volatile and the relationship with a region could substantially alter over time, above all if we consider that the subordinate entities are not simply passive parts of the equation, but act in the sense of obtaining the best possible position in a game of pressure of various more powerful actors: an example of this are the various political units established in the region of Tabal, in the southeast of Anatolia, in the centuries before the downfall of the Hittite Empire, and which clearly sought to find equilibrium in light of the advances and retreats of Assyria, Urartu, and the kingdom of Phrygia. Between the ninth and seventh centuries, the actions of Assyria in Tabal took various forms: aggression and pillage; establishment of a negotiated patron-client relationship, with the payment of tributes; transformation into a directly administered province. A trajectory which was punctuated by defections, treasons, and rebellions, of which the annals of Sargon II provide a vivid sample. ${ }^{21}$ In general, to return to Parker, in the Upper Tigris region, interactions with the political, geographic, and cultural realities of the Anatolian highlands compose a "multifaceted frontier zone" or, better still, a "series of overlapping frontier zones" (Parker, 2002, p.392). In the opposite sense, the same phenomenon occurred: local political elites adjusted their internal relations in functional with repositioning in the external scenario. Many elements which, in principle, indicate a reinforcement of the autonomy of the monarchy (such as royal genealogical lists or monumental statues) actually serve as mechanisms of cultural resistance, allowing the adopting of more advantageous positions in relation to invaders who could not be halted by arms and, at the same time, providing a discourse to an elite which needed to maintain dominion over the internal population,

21 In relation to the changing relations between Assyria and Tabal, cf. MELVILLE, 2010. Specifically for the kingdom of Sargon, see MELVILLE, 2016, p.143 and ss. 
in a moment of greater financial restriction, due to the duty of paying tributes to Assyria. ${ }^{22}$

Obviously, in practices and in representations the system had important cracks. Friction at the heart of Assyrian politics could be considered the most elementary level of structural vulnerability of empire, only partially compensated by conquests.

The synthesis that emerges from this scenario suggests a model of imperialism that to a great extent was an alternative to more traditional visions, which suffer from a certain anachronism: ${ }^{23}$ instead of a compact hegemonic and territorially continuous bloc, created and expanded by successive annexations, what can be seen is a fragmented landscape, linked through the lines of connections and nuclei spread through the periphery and the settlement of porous zones. In other words, a network imperialism. Added to the capital of the kingdom and its environs were entire intermediary zones which not subjected to Assyrian command; these are the interstices of the network which the central palace sought to monitor, but over which it did not manage to impose a regular and effective rule. In addition to the imperial heart, the periphery was composed of an enormous diversity, with its remote provinces, run by governors (bel pahete), whether Assyrian or autochthone, directly appointed by the king, and a considerable quantity of vassal kingdoms, assisted - or better supervised - by delegates (qepu) of the Assyrian king. ${ }^{24}$ Even further away, on the frontiers of the periphery, autonomous buffer states were tolerated whether because they were in limit situations in which the reach of Assyrian power was already weak and

22 Generally speaking, this is context of the small kingdom of Gurgum, in the same region as Tabal. Lynn Swartz Dodd's analysis, which detailed this case, has the great merit of mapping the mutations from the point of view of Assyrian vassals, cf. DODD, 2013.

23 In relation to what follows, see: BERNBECK, 2010; PARKER, 2001, above all Chapter 6. The new approach had already been anticipated by LIVERANI, 1988. For an evaluation of the general state of the debate, see LIVERANI, 2017, p.1 and ss.

24 The duality which emerges in imperial nomenclature at the end of the ninth century BCE, contrasting the 'land of Assur' and the 'yoke of Assur' corresponds to this situation, although it simplifies it. POSTGATE, 1992. 
the investment of the conquest was disproportional to the benefits, or because they fulfilled a role of an obstacle serving as protection against even longer-lasting enemies. Typical cases of these buffers states are the small kingdoms of Shubria, Kumme, Ukku, Musasir, and others (most from Hurrian ethnic or linguistic strata), which separated Assyria from the powerful kingdom of Urartu to the northeast, located at the gateway to a large passage between the Van and Urmia lakes. ${ }^{25}$ Generally speaking, the same occurred in interstice zones which, not being gifted with a state structure, presented themselves as relatively neutral vacuums, conferring a sense of security for the political entities they separated.

In this context, the routes which interconnected the center to the knots of the network - some considered as royal roads ( hul šarri) permitted, under the protection of garrisons, the movement of troops, goods, expatriated populations, messengers, and all sorts of travelers. ${ }^{26}$ It is significant that, in addition to tax collection, land management, the obtaining of raw materials, and carrying out construction works, one of the principal functions of local governors was to guarantee the storing of grains and forage to feed the men and animals who composed the military forces of an empire in constant movement. ${ }^{27}$ It is a predominantly terrestrial movement, but Assyrian expansion would also explore in an unprecedented manner rivers as a form of transport and, with the conquest of a large part of the coast of the Levant, even the sea, previously practically absent in Mesopotamian history, would come to compose the logistics of empire (Fantalkin; Tal, 2015). Communication networks, materialized through the frenetic circulation of royal correspondence, acquired crucial importance, assuring the flow of orders and information between the capital and the other regions of

25 See the detailed study by RADNER, 2012.

26 The network of Assyrian roads prefigured the routes that were important for the Persian advance to the west, two centuries later, BRIANT, 2012, p.186, and continued to be operational for the entire pre-Islamic period and even after, SILVERSTEIN, 2007, p.12 and ss.

27 For this role of governors, see: KEREKES, 2011, pp.106-108. 
the empire, and vice-versa. ${ }^{28}$ In the most complete study of movements within the Assyrian empire, Sabrina Favaro explores in detail this situation which, ultimately, "does not create a uniform, continuous, and coherent geographic and territorial extension, but an expansion carried out over the territory in a discontinuous and fragmented manner" (Favaro, 2007, p.95).

In relation to what most interests us here, a greater implication of this model is the increase in the military apparatus as a mechanism of imperial power and administration. War very much exceeded the function of instrument of conquest and the maintenance of external order, transforming it into a tool of continuous administration. As Bernbeck noted, "if a territorial empire mainly works through an administrative dispositive of power, in the case of network empires, the military prevails" (Bernbeck, 2010, p.156). The brutality of Assyrian actions, as well as their representations, thus arise out of the very nature of the imperial system. Systematic warlike interventions, destruction as a daily form of conflict regulation, particularly in the case of insubordination and rebellions, and the militarization of political relations, internally and externally, all emerged in a context of the absence or weakness of other imperial mechanisms of control. ${ }^{29}$ In the Assyrian case, to a certain extent war is empire.

The Assyrian imperial model, based on extreme bellicosity and permanent violence is not, therefore, the result of a character trait or of an ethnic nature. It is a historic response to the new structural conditions which emerged at the end of the Bronze Age. In the first millennium, the gradual advance in the use of iron in the manufacture of weapons and in the military apparatus in general led to a sensitive change in the control

28 See RADNER, 2014. Added to this external correspondence was a considerable exchange of letters within the court itself, between the servant elite and the sovereign, for a typology, cf. RADNER, 2015.

29 Even some traditional syntheses noted that the essence of imperial administration remained linked to armies and the militaries simultaneously occupied the principal administrative posts; this is the case of GRAYSON, 1995, p.963, who does not, however, formulate, based on these elements, a conceptualization of the nature of Assyrian expansionism. 
of the exercise of terror (Meyer, 2006). The palace monopoly over bronze which had existed in the second millennium, based on the restricted access to sources of copper and tin, far from Mesopotamia, and the limited knowledge of the alloy production process, gave way to a pulverization of metallurgy, allowing a more systematic entrance into the universe of metallurgy, both of groups from outside the palace and from more modest kingdoms. Great powers, such as Assyria and Babylonia, could no longer base their strength on the exclusive use of the metallic apparatus. The emergence of new kingdoms in the Levant, resulting from the reflux of traditional powers, was largely based on the use of iron for military purposes (Liverani, 2005a, p.50 and ss). When the expansionist Mesopotamian centers retook control of the process, a new logic was imposed and war came to be the principal instrument of imperial dominion. Both Assyria and Babylonia managed to channel the new metallurgy to their benefit: it suffices to note the role of iron in the growing importance of infantry and cavalry, to the detriment of battles centered on chariots, typical of the second millennium (Fales, 2010, p.104). In this context, the growth in bellic references - in texts and images - was a full part of the movement and not just a secondary consequence, ${ }^{30}$ and sought to confer discursive consistency on a flaccid dominion and to cement the identity of a warrior elite around an imperial project.

\section{HOLY WAR, RITUAL IMAGE, AND SACRIFICIAL VIOLENCE}

With this we can return to the severed head of Teumman.

Frequently, the approaches to Neo-Assyrian reliefs are limited to taking them as a documental base for a factual constitution of the conflicts. In this perspective, images are assessed as narratives of events, approximating or moving away from reality in function of a greater or lesser intervention of ideological manipulation to which they submitted

30 Overcoming an approach which relegated image to the category of a reflexive by-product of the social process has been sought in some works, cf. PORTER, 1993. 
upon their creation. ${ }^{31}$ It is, thus, an impoverishing approach, which reproduces, for the iconographic sources, a method already recognized to be limited for written documents. Evidentially, an adequate heuristic use of images can help consolidate the collection of information about more concrete aspects of war, from armaments to battle tactics, ${ }^{32}$ but the pictographic evidence should not be taken at face value, since the discursive construction operated at the level of selection and the modes of presentation of figurative events (Fuchs, 2011, p.385). At the interpretative level, therefore, the analysis can advance more. Zainab Bahrani has argued against what she considers is an erroneous vision of the nature of the Assyrian image (and more generically Mesopotamian), which creates considerable obstacles for its historical appreciation: focusing on the essential part, at the core of Bahrani's argument is the questioning of the automatic application of the notion of the representation, based on formal appearance, to Mesopotamian images; according to her, the image constitutes an essential and immanent presence, which cannot be captured by the mimetic concepts of representation on which the Western tradition of the history of art is based. Conceived in this way, the image assumes a performative potential (including a ritual one as we will see), indispensable for the correct understanding of its social role (Bahrani, 2003, especially Chapter 5). ${ }^{33}$

Bahrani's analysis of the iconography of Teumman offers some interesting elements. ${ }^{34}$ The centrality of the severed head of the Elamite king moves the narrative of the events themselves to the background:

31 The deception resulting from the search for a chain of events was, to a great extent, responsible for the idea that the potential narrative Assyrian 'art' was missing, cf. REED, 2007, p.102, no.3.

32 See, for example, the excellent works by NADALI, 2010; 2005.

33 See, in the same sense, the theoretical formulations of BELTING, 1994. A recently defended doctoral dissertation in the Universidade Nova de Lisboa developed a broad analysis of the questions treated here: PAIVA DO MONTE, 2016, p. 25 and ss and 116 ss about the ontological status of the image in Mesopotamia and the notions of presence and agency; p. 245 and ss for the performative dimension of the ritual and p. 71 and ss for Teumman's iconography. The text was kindly bought to my attention by the author when this article had already been submitted for publication, which prevented a more general of an assimilation of its results.

34 For what follows, BAHRANI, 2008, Chapter 1; 2005, 115-119. 
the factual chain of events stops being the guide wire for the appreciation of various panels, which equally applies to the texts which deal with the same theme. ${ }^{35}$ As a type of 'message-sign', containing meaning and conducting visual expression, Teumman's head is not reduced to an exhortation of atrocities or an ostensive demonstration of Assyrian power over other peoples. More powerfully, it vectorizes in a ritual sense, in the form of the fulfillment of a prophecy prior to the decapitation and mentioned in the texts, signaling the consummation of a divine decree. In the inscriptions, Ishtar of Arbela, Assur, Marduk and his son Nabu appear among the divinities who, in different moments, incite the punishment or receive the offering of the head of the Elamite king. However, this is not, at least not primarily, a simple artifice of exhibition, although this aspect is also present: separated from his body, the head is conspicuously hung from the gate of Nineveh. The textual and iconographic compositions highlight the ritual act, a performance in which the severed head is an element that 'could make things happen', like every item which excels through its function of magical and apotropaic evocation. ${ }^{36}$ Like ritually repeated words, the images are limited to symbolizing or describing. Beyond the strict representation, they act, intervene, they are efficient presences, Bahrani states. It is this repetition, through the (apparently) redundant profusion of forms, which makes the visual object exercise a generating fascination: as in enchantments, the formulating multiplication induces a constant movement that causes effects, both in those officiating and in the audience. This phenomenon, so well known

35 The factual chain, however, does not disappear. Analyzing the same series of reliefs and texts, Chikako Watanabe preferred to highlight the 'continuous style', the effect of the temporal and spatial succession of various panels, which also supplied an exact sense of the readings of images based on the sequence of episodes, cf. WATANABE, 2005.

36 In the same form that the image of the king is cloaked in ritual effectiveness in various situations, WINTER, 1992. However, see the reservations of Seth Richardson about the ritual nature of the images dealt with here and their relations with the oracles about battles, cf. RICHARDSON, 2007, p.199. 
and studied at the level of verbal formulas, ${ }^{37}$ is also reproduced through visual mechanisms.

The ritual aspect of the image of the severed head of Teumman was also emphasized by Dominik Bonatz. ${ }^{38}$ The corporal extirpation implied by the hunt for heads operates a transformation of action and its semantic field, dislocating it from the exhibition of a victory trophy to a sacrificial act. In the specific case of the suspended head of the Elamite king, this does not involve a generic demonstration of brutality through the accumulation of mutilations, otherwise so common in the rest of the Neo-Assyrian imagery, but in a singular act, with equally determinant ritual potential. Bonatz calls attention to the parallels between the libations over the body of the hunted lion, in the reliefs of the same Ashurbanipal, and the sprinkling of wine over the heads of Teumman and his allies, an absolutely exceptional treatment in relation to human remains. He also calls attention to the religious nature of the consecration of the severed head to the gods, which approximates this episode to the passage in which Gilgamesh and Enkidu bring to Nippur, the holy city par excellence, the head of Humbaba, guardian of the cedar forest, slain by them in a flamboyant combat. ${ }^{39}$ More generally, the dismemberment of the bodies of enemies slaughtered by the hero is a recurrent theme in mythological narrative. In Lugal-e, the god Ninurta impiously fragments the body of the demon Asakku: "he crushes Asakku like the roasted wheat, emasculates him, and tears him to pieces, like piles

37 This characteristic of oral rites is equally presents in royal inscriptions, whose magical elements were highlighted by ÁRVAI, 2014, p.489 and ss.

38 However, for BONATZ, 2005, the ritualization promoted by Ashurbanipal sought to confer on the singular act (the decapitation of Teumman) the legitimation of a tradition, actually nonexistent, of the decapitation of enemy kings (even if they occurred in isolated cases: such as Esarhaddon, father of Ashurbanipal, who ordered the heads of the kings of Sidon and Kundu to be cut off, and brought to Nineveh). Contra: MAY, 2012, p.471, no.18. May prefers to insert the case of Teumman in a well-established ritual tradition. In my opinion a possible exceptionality of the Teumman case does not remove the ritual dimension of the act which also evokes widely known mythological paradigms, as Bonatz points to and as will be seen later.

39 Epic of Gilgamesh, Tablet V, 300 and ss; of the standard version. cf. GEORGE, 2003 p.615. 
of bricks." ${ }^{40}$ In Enuma eliš, the great epic of the ascension of Marduk, the dismemberment of the body of Tiamat is in the same origin of the cosmogonic action of the Babylonian god: after having slain the great primordial divinity of the salt water sea, Marduk "rested, surveying the corpse, in order to divide the lump by a clever scheme. He split her into two like a dried fish" and the parts of the body created all order; ${ }^{41}$ after this, the blood of Qingu, lover and leader of the troops of Tiamat, would provide the blood for the creation of humanity. ${ }^{42}$

Assyrian visual and textual narratives about the dismemberment of bodies thereby update, in a 'historical' (in other words factual) key, the treatment of enemies in mythological conflicts, permitting the king to be inscribed in the cosmic process of the creation of order and the fight against evil (De Backer, 2010), translating this ritually to the spacetemporal terrain. ${ }^{43}$ Moreover, the act consumed a transformation which only the ritual could provide: as Jean-Jacques Glassner observed, "once he is dead and decapitated, the vital and hostile forces of the enemy were metamorphized into propitiatory forces" (Glassner, 2006, p.50), coming to serve as a protective shield of the victorious god or as the raw material of creation.

Since the general character is reproduced in each of its components, it is not too much to add that the significant moment of triumph and its figurations share the same ritual dimension. The triumphant parade of the king, which follows the receipt of plunder and prisoners, his victorious entrance to the gates of the city or the encampment is nominated

40 Lugal.e (also known Ninurta and the Stones), 1. 294 and ss. Translation in BOTTÉRO; KRAMER, 1989, p.351. Equally, crumbling would be the destiny of the Stones from the mountain which formed Asakku's fleet. The case of Ninurta is particularly relevant, since he, not Assur, is the god of the first new royal capital, Kalhu, cf. ANNUS, 2002, p.42 and ss.

41 Enuma eliš, Tablet IV, 136 and ss. The most recent complete edition is by LAMBERT, 2013, p.95. Comments about the creation of the universe, p.169 and ss. The dismembering of Tiamat is followed by the bleeding of her lover and troop leader, Qingu, whose blood serves for the creation of humanity (VI, 29 and ss).

42 Enuma eliš, VI, 29 and ss.

43 According to Nadali, this is a general criterion of Assyrian iconography, whose "narrative modules (...) circumscribe the space of action and humanize the time" (NADALI, 2006, p.296). 
by the same expression which designates the entrance of the god during the festival of Akitu, the commemoration of the new year: erab ali ('entrance to the city'). As Natalie May noted, the appreciation of the set of decorative programs of palace reliefs establishes a clear chain between ritual hunts, libations (over lions and severed head), triumph, and the royal banquet (May, 2012). Inside the palace, the figuration of triumph and its ritual stages transform it into a memory which is not only the depository of the memory of the past, but also in the words of Davide Nadali, a dimension projected into the future (Nadali, 2013, p.90).

The presence of demons in reliefs is another aspect to be noted. ${ }^{44}$ Hybrid beings in general ('Mischwesen'), represented like compositions of parts of animals or in mixtures of human and animal bodies, they people the Mesopotamian imagination evoking unknown and uncontrollable forces, responsible for evils, but also good actions. In addition to the colossi guarding entrances ${ }^{45}$ on the reliefs which covered the walls of Assyrian palaces, demonic figures appear both isolated on large panels and in discrete insertions in the middle of war scenes. An evolution in the repertoire meant that the near monopoly of wise-apkallu in the ninth century of Ashurnasirpal II gave away, from Sargon II onwards, to greater diversity. In the seventh century palaces of Sennacherib and Ashurbanipal, artisans sought inspiration in a source which particularly interests us: the figurations of demons reproduced the creatures which Tiamat brought to life to form his troops and fight the gods. Of the eleven demons named in Enuma eliš (I, 133-142; II, 20-29), six are attested in the reliefs: kullulu (the man-fish); lahmu (the hero with curls in his hair); o mušhuššu (the dragon-serpent); girtablilu (the man-scorpion); ugallu (the lion demon), and uridimmu (the man-lion). In my opinion, the presence of the offspring of Tiamat in the palace

44 In relation to what follows, ATAÇ, 2010, pp.172-189.

45 Curiously absent from Ashurbanipal's north palace. It thus seems that the decorative planning of the sovereign moved away from the palaces of his predecessors, full of colossi: in Nineveh itself (the southwest palace of Sennacherib), in Dur-Sharrukin (Sargon II's new palace) and in Kalhu (the palace of Ashurbanipal II and two colossi of his son, Shalmaneser III, discovered outside the identifiable architectural context); cf. RUSSELL, 1999, p.155. 
imagery operates in a zone of ambiguity, suggesting that adverse forces existed and could be incarnated by the enemies of the kingdom, but also that the sovereign, once victorious, is capable of making them submit and using them to his benefit, in the same manner that the Elamites were put into the service of Assyria. It is significant that the artisans of Sennacherib and Ashurbanipal carefully avoided the presence in a single scene of the king and a demon, at the same time that they substituted demons with the king as officiating at rituals. ${ }^{46}$ On the one hand, they sought to remove the monarch from contamination by the negative potential these ambivalent figures carried, benefactors and evildoers. On the other, they gave the warrior leader magical capacities previously reserved for super-human beings.

These considerations bring us to the holy nature of war. However, a certain care must be taken when evoking this notion. There is not much novelty in noting that in Assyria, as is the case in Mesopotamia in general, war was legitimated by religious discourse. ${ }^{47}$ This trace of mentality was not limited, however, to a simple justification. As stated above, the mundane action of the king prolonged the will of gods on Earth, reiterated the mythical conflict between order and chaos, making war the perfect translation in its human scenario of more universal, more ancestral, and more abstract divine plans. ${ }^{48}$ The binary conception (Fales, 2010, p.82 and ss) between good and evil, between civilized controlled spaces and hostile and savage nature, between Assyrian identity

46 ORNAN, 2005 sees the process as a reduction of the presence of demons, as benevolent beings, in the Sargonic iconography, in favor of the image of the king. It is a possible interpretation, but does not take into account the ambiguity and the conflictive dimension of these hybrid beings, based on the bellic scenario of the reliefs (and their connection with Tiamat and the mythology of Marduk, more than ever being absorbed by the Assyrians at this moment, as noted by ATAÇ, 2010, p.178 and ss); my conclusion is thus distanced from those of Ornan.

47 A detailed inventory is provided by ODED's classical work, 1992. Liverani adds that "the basic intent of the 'holy war' paradigm is to convince the internal public that 'our' war is supported by the gods, that our army is superior to that of the enemy, that we will suffer no casualties, and that the enemy will be punished for its 'original sin' of being an enemy (i.e., for resistance to imperial and divine power)" (LIVERANI, 2005b, p.233 and 2017, p.33 and ss).

48 For the bellic implications of Assyrian cosmology, see: CROUCH, 2009, p.21 and ss. 
and the alterity of the foreigner (distances and differences which the Assyrians generically labelled as nakru), between piety and fear of the gods and impious behavior, this binary concept, we can say, is repeated on the battle field, in the opposition between the heroic king and his sacrilegious enemy. The greatest attribution of the sovereign - an ethical obligation and not only his political right — is to bring the prevailing order in the dominions of Assur to the surrounding chaos (Liverani, 2011, p.263). War is the continuation of religion by other means, if we want to parody Clausewitz. However, and here resides a fundamental difference, 'holy war' in the Assyrian version was deprived of the forced prescription of adoration of a god or obligatory adoption of a pantheon; it also dispensed with the imposition of specific religious worship. ${ }^{49} \mathrm{Sac}-$ rificial offerings to the god Assur - and the other Assyrian gods - by the submitted populations implied the recognition of the superiority of the divinities of the winners, but this were not translated into imposed adoration or the worship of local gods. Many manifestations of the defeated recognize this bivalent dynamic which allowed, for example, the continuity of the worship of Yahweh in Israel..$^{50}$ In addition, demonstrations of reverence to Assur are linked to those devoted to the king (palah ili $u$ šarri = 'fear of god and the king') and mark a further recognition of the sovereignty of the Assyrian monarch - of whose power god is, in the words of Liverani, a hypostasis (Liverani, 1979, p.301) - rather than a strictly religious adhesion. ${ }^{51}$

The Assyrian religious experience was not characterized, at least not sufficiently, by factors essential in other experiences which laid the path of religious imposition or the elimination of other beliefs: the internalization of faith; the idea of radical distinction between true and false

49 FALES, 2010, p.16 and ss. The finding is particularly valid in relation to the arch-rival Babylonia, FRAME, 1997.

50 See: 2, Kings, 17, 25 and ss. COGAN, 1974, p.107 even talks of 'liberal Assyrian religious policies'.

51 For an overview, considering the previous historiography, see HOLLOWAY, 2002, p.65 and ss. 
gods; ${ }^{52}$ the constitution of an obsessive set of dogmas of the value of moral behavior, in general put into writing, etc. Remaining at the level of a ceremonial type religion, centered on the figure of the sovereign, and which lacked a subjective ethical morality, the sacredness of Assyrian war did not evolve into a war of defense and the prescription of the truth of a particular form of the sacred. ${ }^{53}$

It is in the universe of a war conceived as a ceremonial act that the series of images with the severed head of Teumman makes full sense: this is not only a thematic cycle which privileges ritual scenes in the context of war itself (offerings and sacrifices, processions, burning incense, libations, probably divinatory readings of animal entrails); ${ }^{54}$ it is a set of liturgical artifacts, semantic vectors, and agents of sacrificial violence implied in the bellic conflict. The banquet scene is only comprehensible as a culminating moment of a sequence of events of a holy war, in which the image is a participant, situating the consumption and delights of the banquet in their proper ritual context.

\section{ACKNOWLEDgements}

This article is the partial results of research funded by a CNPq Productivity Grant (2016-2019).

\section{Translation from Portuguese into English by: Eoin Paul Oneill eoinpaul.oneill@outlook.com}

52 The so-called 'mosaic distinction,' which is the keystone of the monotheist religion of Israel and the violence which is inherent to its establishment process, according to ASSMANN, $1998 ; 2010$.

53 Liverani emphasizes the difference between the Assyrian-Babylonian religion and the movement (to a large extent reformist) which would characterize religions and ideologies from the so-called 'axial age', in particular the Deuteronomist movement, in Judah. LIVERANI, 2003. For the concept, originating from the reflections of Karl Jasper, cf. the chapters collected by EISENSTADT, 1986.

54 As reported in detail by READE, 2005, p.21 and ss. 


\section{BibLIOGRAPHICAL REFERENCES}

ABUSCH, Tzvi. Hunting in the Epic of Gilgamesh: Speculations on the Education of a Prince. In: COGAN, Mordechai; KAHN, Daniel (eds.) Treasures on Camels'Humps. Jerusalem: The Hebrew University Magnes Press, 2008, p.11-20.

ALBENDA, Pauline. Lions on Assyrian Wall Reliefs. Journal of the Ancient Near Eastern Society, vol. 6, p.1-27, 1974.

ALBENDA, Pauline. Landscape Bas-reliefs in the Bit-Hilani of Ashurbanipal. Bulletin of the American Schools of Oriental Research, n. 224, p.49-72, 1976.

ALBENDA, Pauline. Landscape Bas-reliefs in the Bit-Hilani of Ashurbanipal (cont.). Bulletin of the American Schools of Oriental Research, n. 225, p.29-48, 1977.

ANNUS, Amar. The God Ninurta in the Mythology and Royal Ideology of Ancient Mesopotamia. Helsinki: The Neo-Assyrian Text Corpus Project, 2002. ÁRVAI, T. A. Jenseits der assyrischen Grenze. Das Bild des Feindes in den neuassyrischen Königsinschriften. In: CSABAI, Zóltan (ed.) Studies in economic and social history of the ancient Near East in memory of Péter Vargyas. Budapest, L'Harmattan, 2014, p.485-502.

ASSMANN, Jan J. Moses, the Egyptian. The Memory of Egypt in Western Monotheism. Cambridge, MA: Harvard University Press, 1998.

ASSMANN, Jan J. The Price of Monotheism. Stanford: Stanford University Press, 2010.

ATAÇ, Mehmet-Ali. Tiamat's Brood. In: ATAÇ, Mehmet-Ali. The Mythology of Kingship in Neo-assyrian Art. Cambridge: Cambridge University Press, 2010. p.172-189.

ATAÇ, Mehmet-Ali. "The Charms of Tyranny": Conceptions of Power in the "Garden Scene" of Ashurbanipal Reconsidered. In: WILHELM, Gernot (ed.) Organization, Representation, and Symbols of Power in the Ancient Near East. Winona Lake: Eisenbrauns, 2012. p.411-427.

BAGG, Ariel M. Die Assyrer und das Westland: Studien zur Historischen Geographie und Herrschaftspraxis in der Levante im 1. Jt. V. u. Z. Leuven: Peeters Publishers, 2011. 
BAGG, Ariel M. Palestine under Assyrian Rule. A New Look at the Assyrian Imperial Policy in the West. Journal of the American Oriental Society, vol. 133, n. 1, p.119-144, 2013.

BAHRANI, Zainab. The Graven Image. Representation in Babylonia and Assyria. Philadelphia: University of Pennsylvania Press, 2003.

BAHRANI, Zainab. The King's Head. In: COLLON, Dominique; GEORGE, Andrew (eds.). Nineveh. vol. 1. London: British School of Archaeology in Iraq 2005. p.115-119.

BAHRANI, Zainab. Rituals of War. The Body and Violence in Mesopotamia. New York, Zone Books, 2008.

BARJAMOVIC, Gojko. Propaganda and Practice in Assyrian and Persian Imperial culture. In: BANG, Peter Fibiger; KOLODZIEJCZYK, Dariusz (eds.). Universal Empire. A Comparative Approach to Imperial Culture and Representation in Eurasian History. Cambridge: Cambridge University Press, 2012. p.43-59.

BARNETT, Richard. Sculptures from the North Palace of Assurbanipal at Nineveh, 668-627 B.C. London: The British Museum, 1976.

BARNETT. Richard; BLEIBTREU, Erika; TURNER, Geoffrey. Sculptures from the Southwest Palace of Sennacherib at Nineveh. London: British Museum Press, 1998.

BEDFORD, Peter R. The Neo-Assyrian Empire. In: MORRIS, Ian; SCHEIDEL, Walter (eds.). The Dynamics of Ancient Empires. State Power from Assyria to Byzantium. Oxford: Oxford University Press, 2009. p.30-65.

BELTING, Hans. Likeness and Presence. A History of the Image before the Era of Art. Chicago: The University of Chicago Press, 1994.

BENOIT, Agnès. Art et archéologie. Les civilisations du Proche-Orient ancien. Paris : Éditions de la Réunion des Musées Nationaux, 2003.

BERNBECK, Reinhard. Imperialist Networks: Ancient Assyria and the United States. Present Pasts, vol. 2, n.1, p.142-168, 2010.

BOHRER, Frederick Nathaniel. Inventing Assyria: Exoticism and Reception in Nineteenth-century England and France. The Art Bulletin, vol. 80, n. 2, p.336-356, 1998. 
BONATZ, Dominik. Ashurbanipal's Headhunt: an Anthropological Perspective. In: COLLON, Dominique; GEORGE, Andrew (eds.). Nineveh. vol. 1. London: British School of Archaeology in Iraq, 2005. p.93-101.

BORGER, Riekele. Beiträge zum Inschriftenwerk Assurbanipals: Die Prismenklassen $A, B, C=K, D, E, F, G, H$, J und T sowie andere Inschriften. Wiesbaden: Harrassowitz, 1996.

BOTTÉRO, Jean; KRAMER, Samuel Noah. Lorsque les dieux faisaient l'homme. Paris: Gallimard, 1989.

BRIANT, Pierre. From the Indus to the Mediterranean: The Administrative Organization and Logistics of the Great Roads of the Achaemenid Empire. In: ALCOCK, Susan Ellen et alii (eds.). Highways, Byways, and Road Systems in the Pre-modern World. Oxford: Blackwell, 2012. p.185-201.

BRINKMAN, John Anthony. Babylonian under the Assyrian Empire - 745627 B.C. In: LARSEN, Mogens Trolle (ed.). Power and Propaganda. A Symposium on Ancient Empires. Copenhagen: Akademisk Forlag, 1979. p.223-250.

BRINKMAN, John Anthony. Prelude to Empire. Babylonian Society and Politics, 747-626 B.C. Philadelphia, Occasional Publications of the Babylonian Fund, 7, 1984.

CARAMELO, Francisco. A crise política e militar de Shamash-shumu-ukin no reinado de Assurbanipal: os ecos na Adivinhação. In: RAMOS DOS SANTOS, António; VARANDAS, José (ed.). A guerra na Antiguidade. vol. 3. Lisboa: Caleidoscópio-Centro de História da Faculdade de Letras da Universidade de Lisboa, 2010. p.65-82.

CARAMELO, Francisco. Território, fronteira e expansão no período mesoassírio: a presença assíria no Eufrates-Médio. Cadmo, n. 21, p.33-50, 2011.

CASSIN, Elena. Le roi et le lion. In: CASSIN, Elena. Le semblable et le différent. Symbolisme du pouvoir dans le Proche-Orient ancien. Paris : Éditions la Découverte, 1987. p.167-212.

COGAN, Morton. Imperialism and Religion. Assyria, Judah and Israel in the Eight and Seventh Centuries B.C.E. Missoula, Montana: Society of Biblical Literature, 1974. 
COLLINS, Paul. Assyrian Palace Sculptures. Austin, University of Texas Press, 2008.

CROUCH, C. L. War and Ethics in the Ancient Near East. Military Violence in Light of Cosmology and History. Berlin: Walter De Gruyter, 2009.

De BACKER, Fabrice. Fragmentation of the Enemies in the Ancient Near East during the Neo-Assyrian Period. In: MICHAELS, Axel. (ed.). Ritual Dynamics and the Science of Ritual. vol. III: State, Power and Violence. Section III: Usurping Ritual. Wiesbaden: Harrassowitz Verlag, 2010. p.393-412.

DEMARE-LAFONT, Sophie. Fief et féodalité dans le Proche-Orient ancien. In: BOURNAZEL, Éric; POLY, Jean-Pierre (eds.). Les féodalités. Paris: PUF, 1998. p.513-630.

DODD, L. S. Monuments of Resistance. Gurgum and the Assyrian Conquest. In: ARERSHIAN, Gregory E. (ed.). Empires and Diversity. On the Crossroads of Archaeology, Anthropology, and History. Los Angeles: Cotsen Institute of Archaeology Press, 2013. p.57-83.

EISENSTADT, Shmuel N. (ed.). The Origins and Diversity of Axial Age Civilizations. New York: State University of New York Press, 1986.

FALES, Frederick Mario. Narrazione visuale e testuale: il caso dele campagne militari assire. In: INVERNIZZI, A. et alii (eds.). Larte nel Vicino Oriente Antico. Belezza, rappresentazione, espressione. Milano: Edizioni Ares, 2006. p.79-116.

FALES, Frederick Mario. Guerre et paix en Assyrie. Religion et impérialisme. Paris: Cerf, 2010.

FANTALKIN, Alexander; TAL, Oren. When the River Meets the Sea. A Neo-Assyrian Logistical Network in Operation. Skyllis, vol. 15, n. 1, 2015. p.21-27.

FAVARO, Sabrina. Voyages et voyageurs à l'époque néo-assyrienne. Helsinki: The Neo-Assyrian Text Corpus Project, 2007.

FRAHM, Eckart. Images of Assyria in Nineteenth and Twentieth-century Western scholarship. In: HOLLOWAY, Steven W. (ed.). Orientalism, Assyriology and the Bible. Shefield: Shefield Phoenix Press, 2007. p.74-94. FRAME, Grant. The God Assur in Babylonia. In: PARPOLA, Simo; WHITING, Robert McCray (eds.). Assyria, 1995. Helsinki: The NeoAssyrian Text Corpus Project, 1997. p.55-64. 
FUCHS, Andreas. Assyria at War: Strategy and Conduct. In: RADNER, Karen; ROBSON, Eleanor (ed.). The Oxford Handbook of Cuneiform Culture. Oxford: Oxford University Press, 2011. p.380-401.

GALTER, Hannes D. Looking Down the Tigris. The Interrelations between Assyria and Babylonia. In: LEICK, Gwendolyn (ed.). The Babylonian World. New York: Routledge, 2009. p.527-540.

GEORGE, Andrew R. The Babylonian Gilgamesh epic. Volume 1. Oxford, Oxford University Press, 2003.

GERARDI, Pamela. Epigraphs and Assyrian Palace Reliefs: the Development of the Epigraphic Text. Journal of Cuneiform Studies, vol. 40, n. 1, p.3-35, 1988.

GLASSNER, Jean-Jacques. Couper des têtes em Mésopotamie. In: D'ONOFRIO, Salvatori; TAYLOR, Anne-Christinne (eds.). La guerre en tête. Cahiers d'Anthropologie Sociale, 2. Paris: L'Herme, 2006. p.47-55. GRAYSON, A. Kirk. Assyrian Rule of Conquered Territory in Ancient Western Asia. In: SASSON, Jack M. (ed.). Civilizations of the Ancient Near East. vol. 2. New York: Charles Scribner's Sons, 1995. p.959-968.

GRECO, A. Zagros Pastoralism and Assyrian Imperial Expansion: a Methodological Approach. In: LAFRANCHI, G. B.; ROAF, M.; ROLLINGER, R. (eds.). Continuity of Empire (?) Assyria, Media, Persia. Padova: Sargon Editrice, 2003. p.65-78.

HOLLOWAY, Steven W. Aššur is king! Aššur is king! Religion in the Exercise of Power in the Neo-Assyrian Empire. Leiden: Brill, 2002.

JURSA, Michael. The Neo-Babylonian Empire. In: GEHLER, M.; ROLLINGER, R. (eds.). Imperien und Reiche in der Weltgeschichte. Epochenübergreifende und globalhistorische Vergleiche. Wiesbaden: Harrassowitz, 2014. p.121-148. KEREKES, Miklós. The Assyrian Provincial Administration. The Neo-Assyrian Governor's Aspects within Their Province. In: PÉTER, J. (ed.). APARKHAI. Lectures Held at the $6^{\text {th }}$ Conference of Collegium Hungaricum Societatis Europaeae Studiosorum Philologiae Classicae. Budapest, 2011. p.104-109.

KERTAI, David. The Architecture of Late Assyrian Palaces. Oxford: Oxford University Press, 2015. 
LAMBERT, Wilfred George. Babylonian creation myths. Winona Lake: Eisenbrauns, 2013.

LARSEN, Mogens Trolle. La conquête de l'Assyrie. Paris: Hachette, 2001. LION, Brigitte; MICHEL, Cécile. Les chasses royales néo-assyriennes. Textes et images. In: SIDERA, Isabelle (ed.). La chasse. Pratiques sociales et symboliques. Paris: De Boccard, 2006. p.217-283.

LIVERANI, Mario. The Ideology of the Assyrian Empire. In: LARSEN, Moges Trolle (ed.). Power and Propaganda. A Symposium on Ancient Empires. Copenhagen: Akademisk Forlag, 1979. p.297-397.

LIVERANI, Mario. The Growth of the Assyrian Empire in the Habur/ Middle Euphrates Area: a New Paradigma. State Archives of Assyria Bulletin, vol. 2, n. 2, p.81-98, 1988.

LIVERANI, Mario. Guerra santa e guerra giusta nel Vicino Oriente Antico (circa 1600-600 A.C.). Studi Storici, vol. 43, n.3, p.639-659, 2003.

LIVERANI, Mario. Más allá de la Biblia. Historia antigua de Israel. Barcelona, Crítica, 2005a.

LIVERANI, Mario. Imperialism. In: POLLOCK, Susan; BERNBECK, Reinhard (eds.). Archaeologies of the Middle East. Critical perspectives. Malden: Blackwell, 2005b. p.223-243.

LIVERANI, Mario. From City-state to Empire: the Case of Assyria. In: ARNASON, Johann P.; RAAFLAUB, Kurt A. (eds.). The Roman Empire in Context. Historical and comparative perspectives. Oxford: WileyBlackwell, 2011. p.251-269.

LIVERANI, Mario. Assyria. The Imperial Mission. Winona Lake: Eisenbrauns, 2017.

LUCKENBILL, Daniel David. Ancient Records of Assyria and Babylonia. vol. 2. London: Glassmill, 1989.

MACGREGOR, S. L. Women in the Neo-Assyrian world: Visual and Textual Evidence from Palace and Temple. PhD. Thesis. Berkeley: University of California, 2003.

MACGREGOR, S. L. Beyond Hearth and Home. Women in the Public Sphere in Neo-Assyrian Society. Helsinki: The Neo-Assyrian Text Corpus Project, 2012. 
MALBRAN-LABAT, Florence. L'armée et l'organisation militaire de l'Assyrie. Genève: Librairie Droz, 1984.

MANN, Michael. The Sources of Social Power. vol 1: A History of Power from the Beginning to A.D. 1760. Cambridge: Cambridge University Press, 1986.

MATTILA, Raija. The King's Magnates. A Study of the Highest Officials of the Neo-Assyrian Empire. Helsinki: The Neo-Assyrian Text Corpus Project, 2000.

MAY, Natalie Naomi. Triumph as an Aspect of the Neo-Assyrian Decorative Program. In: WILHELM, Gernot (ed.). Organization, Representation, and Symbols of Power in the Ancient Near East. Winona Lake: Einsenbrauns, 2012. p.461-488.

MELVILLE, Sarah C. Royal Neo-Assyrian Women and Male Identity: Status as a Social Tool. Journal of the American Oriental Society, vol. 124, n.1, p.37-57, 2004.

MELVILLE, Sarah C. Kings of Tabal: Politics, Competition, and Conflict in a Contested Periphery. In: RICHARDSON, Seth (ed.). Rebellions and Peripheries in the Cuneiform World. New Haven: American Oriental Society, 2010. p.87-109.

MELVILLE, Sarah C. The Campaigns of Sargon II, King of Assyria, 721-705 B.C. Norman, Oklahoma: University of Oklahoma Press, 2016.

MEYER, J. C. Trade in Bronze Age and Iron Age Empires, a Comparison. In: BANG, P. F.; IKEGUCHI, M.; ZICHE, H. G. (eds.). Ancient Economies, Modern Methodologies. Archaeology, Comparative History, Models and Institutions. Bari: Edipuglia, 2006. p.89-106.

NADALI, Davide. Assyrians to War: Positions, Patterns and Canons in the Tactics of the Assyrian Armies in the VII Century B.C. In: LUDOVICO, Alessandro Di; NADALI, Davide (eds.). Studi in onore di Paolo Mathiae presentati in ocasione del suo sessantacinquesimo compleanno. Roma: CMAO, 2005. p.167-207.

NADALI, Davide. Percezione dello spazio e scansione del tempo. Studio della composizione narrative del relieve assirio di VII secolo a.C. Contributi e Materiali di Archeologia Orientale, vol. 12, p.1-28, 2006. 
NADALI, Davide. Ashurbanipal against Elam. Figurative Patterns and Architectural Location of the Elamite Wars. Historiae, vol. 4, p.57-91, 2007.

NADALI, Davide. Assyrian Open Field Battles. An Attempt at Reconstruction and Analysis. In: VIDAL, Jordi (ed.). Studies on War in the Ancient Near East. Collected Essays on Military History. Münster: Ugarit Verlag, 2010. p.117-152.

NADALI, Davide. Outcomes of Battle: Triumphal Celebrations in Assyria. In: SPALINGER, Anthony; ARMSTRONG, Jeremy (eds.). Rituals of Triumph in Mediterranean World. Leiden: Brill, 2013. p.75-94.

ODED, Bustenay. Peace and Empire. Justifications for War in Assyrian Royal Inscriptions. Wiesbaden: Ludwig Reichert Verlag, 1992.

ORNAN, Tallay. Expelling Demons at Nineveh: on the Visibility of Benevolent Demons in the Palaces of Nineveh. In: COLLON, Dominique; GEORGE, Andrew (eds.). Nineveh. Vol. 1. London: British School of Archaeology in Iraq, 2005. p.83-92.

PAIVA DO MONTE, M. L. Ideia e presença: a imagem do rei na construção simbólica do espaço imperial neo-assírio (sés. X-VII a.C.). Tese de doutorado. Universidade Nova de Lisboa. Dezembro de 2016.

PARKER, Bradley. J. The Mechanics of Empire. The Northers Frontier of Assyria as a Case Study in Imperial Dynamics. Helsinki: The Neo-Assyrian Text Corpus Project, 2001.

PARKER, Bradley J. At the Edge of Empire. Conceptualizing Assyria's Anatolian Frontier ca. 700 BC. Journal of Anthropological Archaeology, vol. 21, p.371-395, 2002.

PARPOLA, Simo. Assyria's Expansion in the 8th and 7th Centuries and its Long Term Repercussions in the West. In: DEVER, William G.; GITIN, Seymour (eds.). Symbiosis, Symbolism, and the Power of the Past. Canaan, Ancient Israel, and their Neighbors from Late Bronze Age through Roman Palestina. Winona Lake: Eisenbrauns, 2003. p.99-111.

PECIRKOVÁ, Jana. The Administrative Organization of the Neo-Assyrian Empire. Archív Orientální, vol. 45, p.211-228, 1977.

PECIRKOVÁ, Jana. Ancient Imperialism. Rome and Assyria, Archív Orientální, vol. 65, p.231-240, 1997. 
PONCHIA, Simonetta. Mountain Routes in Assyrian Royal Inscriptions (part I). Kaskal, vol. 1, p.139-177, 2004.

PONCHIA, Simonetta. Mountain Routes in Assyrian Royal Inscriptions (part II). Archives of Assyria Bulletin, vol. 15, p.193-271, 2006.

PORTER, Barbara N. Images, Power, Politics. Figurative Aspects of Esarhaddon's Babylonian Policy. Philadelphia: American Philosophical Society, 1993.

PORTER, Barbara N. "For Astonishment of all Enemies": Assyrian Propaganda and its Audiences in the Reigns of Ashurnasirpal II and Esarhaddon. Bulletin of the Canadian Society for Mesopotamian Studies, vol. 35, p.7-18, 2000.

PORTER, Barbara N. Intimidation and Friendly Persuasion. Re-evaluating the Propaganda of Assurnasirpal II. In: PORTER, Barbara N. Trees, Kings, and Politics. Studies in Assyrian Iconography. Fribourg: Academic Press Fribourg, 2003, p.81-97.

POSTGATE, John Nicholas. The Land of Assur and the Yoke of Assur. World Archaeology, vol. 23, p.247-263, 1992.

RADNER, Karen. Royal Decision-making: Kings, Magnates, and Scholars. In: RADNER, Karen; ROBSON, Eleanor (eds.). The Oxford Handbook of Cuneiform Culture. Oxford, Oxford University Press, 2011. p.358-379. RADNER, Karen. Between a Rock and a Hard Place: Musasir, Kumme, Ukku and Shubria - the Buffer States between Assyria and Urartu. In: KROLL, S. et alii (eds.). Biainili-Urartu. Leuven: Peeters, 2012. p.243-264. RADNER, Karen. An Imperial Communicational Network. The State Correspondence of the Neo-Assyrian Empire. In: RADNER, Karen (ed.). State Correspondence in the Ancient World. From New Kingdom Egypt to the Roman Empire. Oxford: Oxford University Press, 2014. p.64-93. RADNER, Karen. Royal Pen Pals. The Kings of Assyria in Correspondence with Officials, Clients and Total Strangers $\left(8^{\text {th }}\right.$ and $7^{\text {th }}$ centuries BC). In: PROCHÁZKA et alii (eds.). Official Epistolography and the Language(s) of Power. Wien: Verlag de Österreischschen Akademie der Wissenschaften, 2015. p.61-72. 
READE, Julian. Ideology and Propaganda in Assyrian Art. In: LARSEN, Mogens Trolle (ed.). Power and Propaganda. A Symposium on Ancient Empires. Copenhagen, 1979. p.329-343.

READE, Julian. Assyrian Sculpture. $2^{\mathrm{a}}$ ed. London: British Museum Press, 1998.

READE, Julian. Religious Ritual in Assyrian Sculpture. In: PORTER, Barbara N. (ed.). Ritual and Politics in Ancient Mesopotamia. New Haven: American Oriental Society, 2005. p.7-61.

REED, Stephanie. Blurring the Edges: a Reconsideration of the Treatment of Enemies in Ashurbanipal's Reliefs. In: CHENG, Jack; FELDMAN, Marian H. (eds.). Ancient Near Eastern Art in Context. Leiden: Brill, 2007. p.101-130.

RICHARDSON, Seth. Death and Dismemberment in Mesopotamia. In: LANERI, Nicola (ed.). Performing Death. Social Analyses of Funerary Traditions in the Ancient Near East and Mediterranean. Chicago: The Oriental Institute, 2007. p.189-208.

RICHARDSON, Seth. Getting Confident. The Assyrian Development of Elite Recognition Ethics. In: LAVAN, Myles et alii (eds.). Cosmopolitanism and Empire. Universal Rulers, Local Elites, and Cultural Integration in the Ancient Near East and Mediterranean. Oxford: Oxford University Press, 2016. p.26-64.

RUSSELL, John Malcolm. Sennacherib's Palace without Rival at Nineveh. Chicago: The University of Chicago Press, 1991

RUSSELL, John Malcolm. The Writing on the Wall. Studies in the Architectural Context of Late Assyrian Palace Inscriptions. Winona Lake: Eisenbrauns, 1999.

SAYCE, Archibald Henry. Assyria. Its Princes, Priests, and People. London: The Religious Tract Society, 1895 [original de 1885].

SILVERSTEIN, Adam J. Postal System in the Pre-modern Islamic World. Cambridge: Cambridge University Press, 2007.

SVÄRD, Saana. Women and Power in Neo-Assyrian Palaces. Helsinki: The Neo-Assyrian Text Corpus Project, 2015.

TENU, Aline. L'expansion médio-assyrienne. Approche archéologique. Oxford: BAR International Series, 2009. 
VILLARD, Pierre. L'empire néo-assyrien. In: HURLET, Frédéric. (ed.). Les empires. Antiquité et Moyen Âge, analyse comparée. Rennes, Presses Universitaires de Rennes, 2008. p.15-31.

WATANABE, Chikako Esther. Symbolism of the Royal Lion Hunt in Assyria. In: PROSECKY, J. (ed.). Intellectual Life of the Ancient Near East. Prague: Oriental Institute, 1998. p.439-450.

WATANABE, Chikako Esther. The Lion Metaphor in the Mesopotamian Royal Context. Topoi, Supplement, vol. 2, p.399-409, 2000.

WATANABE, Chikako Esther. The "Continuous Style" in the Narrative Scheme of Assurbanipal's Reliefs. In: COLLON, Dominique; GEORGE, Andrew (eds.) Nineveh. Vol. 1. London: British School of Archaeology in Iraq, 2005. p.103-114.

WATERS, Matthew William. A Survey of Neo-Elamite History. PhD. University of Pennsylvania, 1997.

WATERS, Matthew William. Te'umman in the Neo-Assyrian Correspondence. Journal of the American Oriental Society, vol. 119, n. 3, p.473-477, 1999.

WEINFELD, M. The Protest Against Imperialism in Ancient Israelite Prophecy. In: EISENSTADT, Shmuel N. (ed.). The Origins and Diversity of Axial Age Civilizations. New York: State University of New York Press, 1986. p.169-172.

WEISSERT, Elnathan. Royal Hunt and Royal Triumph in a Prism Fragment of Ashurbanipal (82-5-22,2). In: PARPOLA, Simo; WHITING, Robert McCray (eds.) Assyria, 1995. Helsinki: The Neo-Assyrian Text Corpus Project, 1997. p.339-358.

WINTER, Irene. 'Idols of the King': Royal Images as Recipients of Ritual Action in Ancient Mesopotamia. Journal of Ritual Studies, vol. 6, n. 1, p.13-42, 1992. 